\title{
Leprosy in the elderly population of Alagoas
}

David Darnis Bezerra da Silva'

Clodis Maria Tavares²

Nataly Mayara Cavalcante Gomes ${ }^{3}$

Aline Costa Cardoso $0^{4}$

Ricardo Alexandre Arcêncio ${ }^{5}$

Paula Sacha Frota Nogueira

\section{Abstract}

Objective: to describe the epidemiological profile of elderly persons with leprosy in the state of Alagoas. Method: a descriptive epidemiological study of leprosy cases among the elderly reported to the Disease Notification Information System between 2005 and 2015 was carried out. Results: a total of 896 cases were identified, with a predominance of 60-69 years old (60.5\%), who were male (50.4\%), had no schooling (34.8\%), no source of income $(54.1 \%)$, multibacillary forms of the disease $(67.9 \%)$, and a high proportion of grade I (30.3\%) and II (11.8\%) disability at diagnosis. Hyperendemicity was noted during the survey period, with a mean detection rate of 29.48 cases per 100,000 inhabitants.

Keywords: Leprosy. Epidemiology Descriptive. Elderly. Conclusion: leprosy is a growing disease among the elderly and early detection should be encouraged in this population to prevent the impairment of active aging.

\footnotetext{
Universidade Federal de Alagoas, Programa de graduação em Enfermagem. Maceió, Alagoas, Brasil.

2 Universidade de São Paulo, Programa de pós-graduação em Ciências. São Paulo, São Paulo, Brasil.

3 Universidade Federal de Alagoas, Programa de graduação em Enfermagem. Maceió, Alagoas, Brasil.

4 Universidade Estadual de Ciências da Saúde de Alagoas, Programa de residência multiprofissional em Saúde da Família. Maceió, Alagoas, Brasil.

5 Universidade de São Paulo, Escola de Enfermagem de Ribeirão Preto, Programa de pós-graduação em Enfermagem. Ribeirão Preto, São Paulo, Brasil.

6 Universidade Federal do Ceará, Programa de pós-graduação em Enfermagem. Fortaleza, Ceará, Brasil.
}

Correspondence

Aline Costa Cardoso

alinecardoso.c@outlook.com 


\section{INTRODUCTION}

The process of population aging is a global reality that brings with it biopsychosocial challenges, as the demographic increase of elderly people influences the organization of the health services and requires a rethink of public policies in order to confer equality and access of health care to these populations ${ }^{1,2}$.

It is estimated that in 2025 Brazil will have the world's sixth oldest population ${ }^{3}$. Long-lived persons often suffer functional loss, which can be accelerated by certain diseases, such as leprosy ${ }^{2}$.

This is a chronic infectious contagious disease that, if not diagnosed, may evolve into the tuberculoid, dimorphic or Virchowian forms. Late diagnosis is related to neural impairment with physical disability, since the course and manifestations of the disease depend on the response of the immune system to the bacillus and symptoms may take up to 20 years to appear ${ }^{4,5}$.

An analysis of all leprosy cases reported from 2012 to 2016 in Brazil revealed that the mean detection rate was approximately eight times higher in the male population aged 60 years and over than in those aged under $15^{6}$.

In this context, it is known that leprosy has a greater impact on the elderly, as Hansen's bacillus features incapacitating vectors, resulting in an impairment of the dynamics of the life of the individual, especially in those where functional capacity is already affected by the natural course of the health-disease process, in addition to affecting personal relationships and the support network ${ }^{7}$.

The study of leprosy in the elderly is therefore pertinent, as this group tends to experience more complex profiles of the disease and it is important to increase our knowledge of the profile of the population of elderly people affected by leprosy. The aim of the present study was therefore to describe the epidemiological profile of elderly people with leprosy in the state of Alagoas.
METHOD

A descriptive epidemiological study of leprosy cases reported in elderly people in Alagoas from 2005 to 2015 was carried out. The data were extracted from the Disease Notification Information System (SINAN) together with the Alagoas State Health Department.

After the data were collected, the information was classified and tabulated according to the research objectives and analyzed descriptively.

Simple descriptive analyzes were performed with the aim of characterizing the study population. The study consisted of sociodemographic (age, gender, race, level of schooling and occupation) and clinical variables (clinical form, operational classification, smear microscopy results, physical disability grade at diagnosis and discharge, number of skin lesions and detection rate). As the study used secondary data it was not submitted to the Ethics Research Committee.

\section{RESULTS}

A total of 896 cases of leprosy were reported in elderly persons between 2005 and 2015, 60.5\% of whom were in the 60-69 age group and $50.5 \%$ of whom were male.

Regarding the clinical form of the disease, the Dimorphous (271 - 30.2\%); multibacillary (608 $67.9 \%)$ form with more than five dermatological lesions (386 - 43.0\%) was prevalent.

In terms of operational classification, a prevalence of multibacillary cases of over ten years was observed.

Regarding the evaluation of physical disabilities caused by leprosy in the diagnosis, grade 0 disability was prevalent (370-41.3\%). However, a considerable percentage (277 - 42.1\%) had grade I or II disability. The categories 'not evaluated' and 'ignored' are noteworthy as they represent 149 cases $(16.6 \%)$. In terms of the assessment of grade of physical disability at discharge, the data show that grade 0 was predominant (280 $31.2 \%$ ), but the 'not evaluated' and 'ignored' variables represented approximately half the cases (398 - 44.4\%). 
Table 1. Sociodemographic characteristics of elderly persons with leprosy ( $\mathrm{N}=896)$.

\begin{tabular}{|c|c|}
\hline Variable & $\mathrm{n}(\%)$ \\
\hline \multicolumn{2}{|l|}{ Age (years) } \\
\hline $60-69$ & $542(60.5)$ \\
\hline $70-79$ & $278(31.0)$ \\
\hline 80 or more & $76(8.5)$ \\
\hline \multicolumn{2}{|l|}{ Gender } \\
\hline Female & $444(49.5)$ \\
\hline Male & $452(50.5)$ \\
\hline \multicolumn{2}{|l|}{ Ethnicity/Skin color } \\
\hline White & $203(22.7)$ \\
\hline Brown & $542(60.5)$ \\
\hline Black & $106(11.8)$ \\
\hline Others and not informed & $45(5.0)$ \\
\hline \multicolumn{2}{|l|}{ Schooling (years) } \\
\hline None & $312(34.8)$ \\
\hline 1 to 3 & $215(24.0)$ \\
\hline 4 to 7 & $106(11.8)$ \\
\hline 8 to 11 & $52(5.8)$ \\
\hline 12 or more & $20(2.2)$ \\
\hline Not informed or non-applicable & $191(21.4)$ \\
\hline \multicolumn{2}{|l|}{ Occupation } \\
\hline Retired & $212(23.7)$ \\
\hline No source of income & $485(54.1)$ \\
\hline Other professions & $199(22.2)$ \\
\hline
\end{tabular}

Table 2. Clinical characteristics of elderly persons diagnosed with leprosy ( $\mathrm{N}=896)$.

\begin{tabular}{ll}
\hline Variable & $\mathrm{n}(\%)$ \\
\hline Clinical form & $80(8.9)$ \\
Indeterminate & $178(19.9)$ \\
Tuberculoid & $271(30.2)$ \\
Dimorphous & $176(19.6)$ \\
Virchowian & $129(14.4)$ \\
Unclassified & $62(7.0)$ \\
Ignored & \\
Operational Classification & $288(32.1)$ \\
Paucibacillary & $608(67.9)$ \\
Multibacillary & \\
Number of Dermatological Lesions & $63(7.1)$ \\
Zero & $170(19.0)$ \\
Single lesion & $277(30.9)$ \\
2 to 5 & $386(43.0)$ \\
More than 5 & \\
Smear microscopy & $371(41.4)$ \\
Ignored & $83(9.3)$ \\
Positive & $107(11.9)$ \\
Negative & $335(37.4)$ \\
\hline Not performed &
\end{tabular}




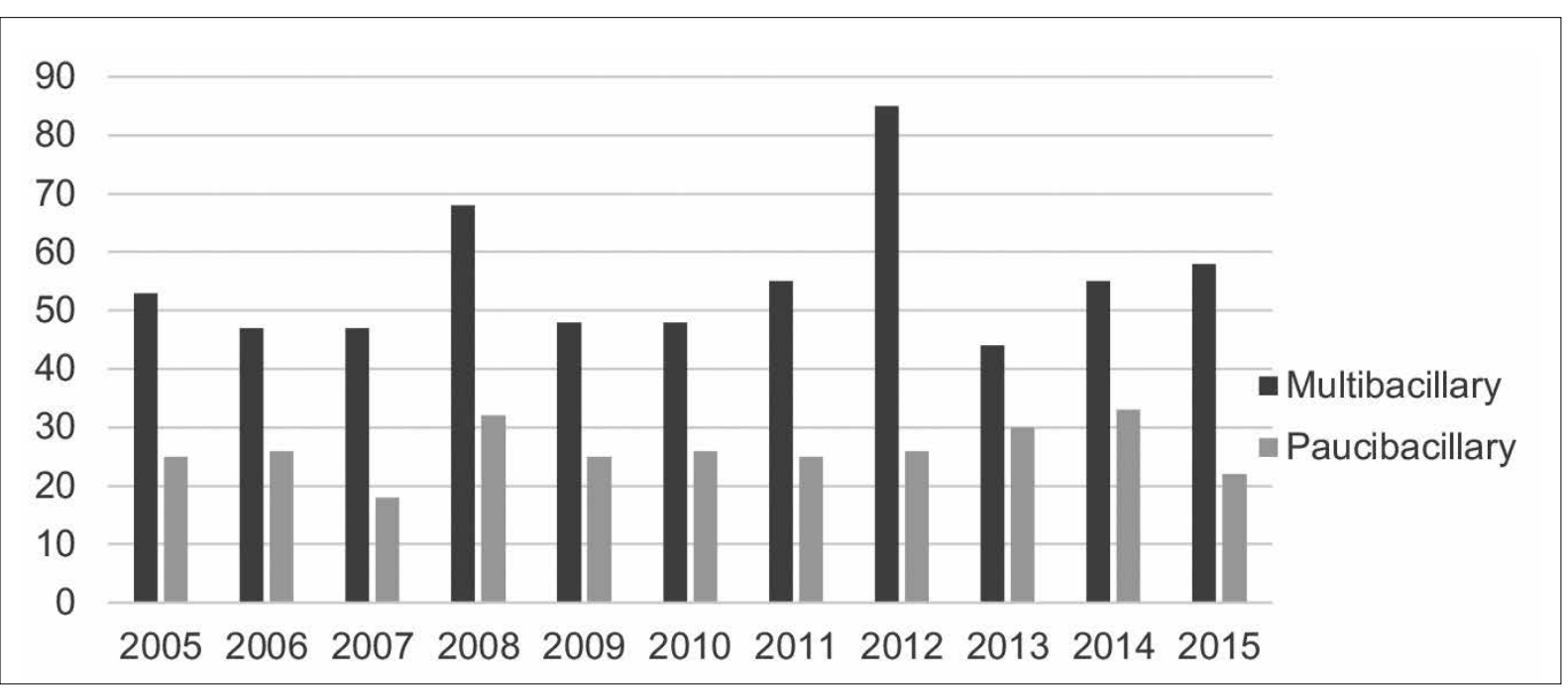

Graph 1. Proportion of cases of leprosy in elderly persons according to operational classification ( $N=896)$.

Table 3. Physical disability (PD) grade in elderly persons with leprosy ( $\mathrm{N}=896$ ).

\begin{tabular}{ll}
\hline Variable & $\mathrm{n}(\%)$ \\
\hline Physical disability grade at diagnosis & \\
Zero & $370(41.3)$ \\
Grade I & $271(30.3)$ \\
Grade II & $106(11.8)$ \\
Not evaluated & $97(10.8)$ \\
Ignored & $52(5.8)$ \\
\hline Grade of physical disability at diagnosis & \\
Zero & $280(31.2)$ \\
Grade I & $151(16.9)$ \\
Grade II & $67(7.5)$ \\
Not evaluated & $134(14.9)$ \\
\hline Ignored & $264(29.5)$ \\
\hline
\end{tabular}

A detection rate of over 20 cases per 100,000 inhabitants was observed, with a mean of 29.48 cases between 2005 and 2015. This data reflects a hyperendemic epidemiological situation in the state, according to the parameters of the Ministry of Health ${ }^{8}$. High rates in 2008 and 2012 (36.20 and 40.19 , respectively) were noted, followed by a sharp drop in subsequent years. 


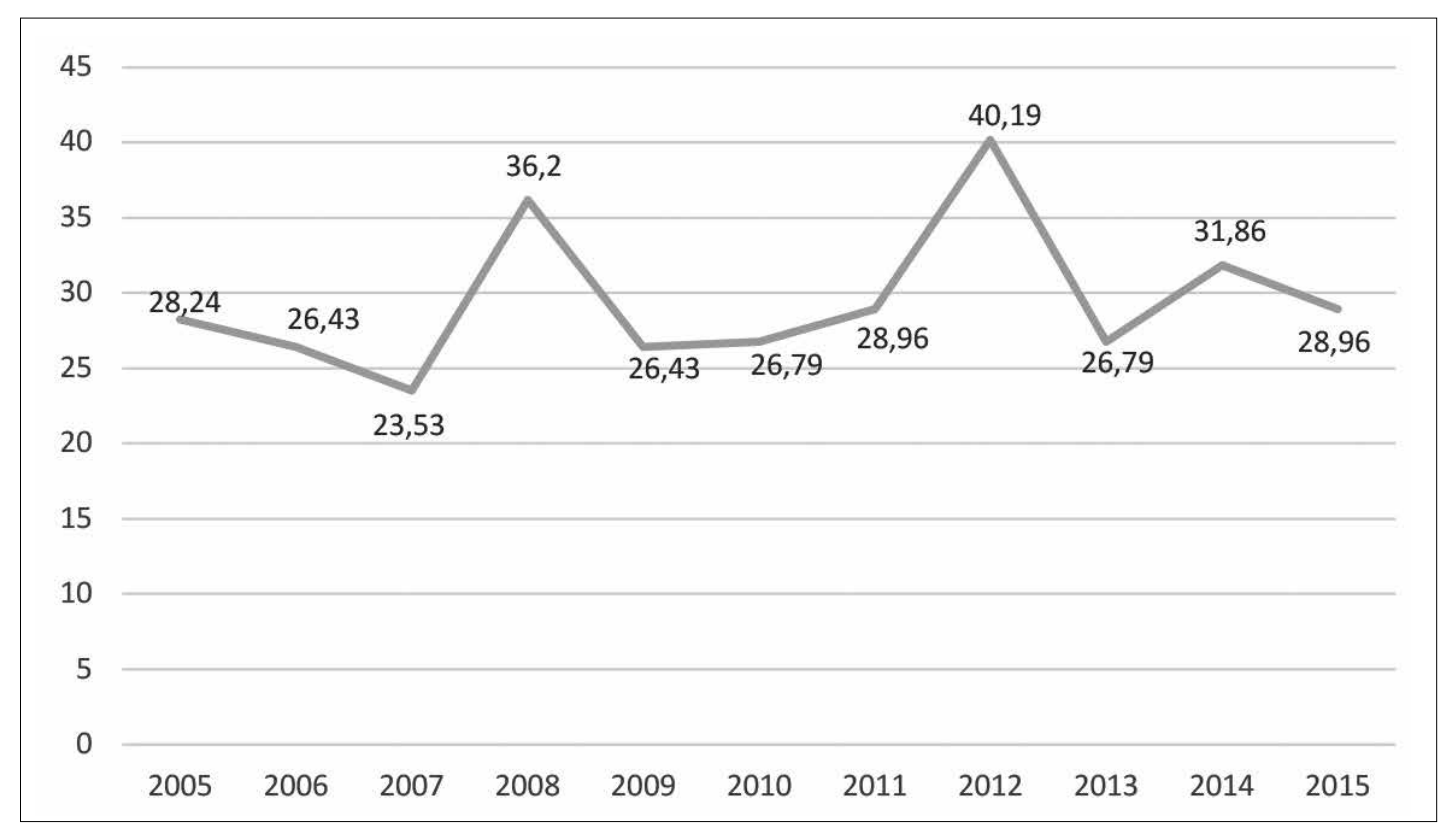

Graph 2. Temporal trend of the detection rate of leprosy cases among the elderly $(\mathrm{N}=896)$.

\section{DISCUSSION}

According to the results of the study, the predominant age group was 60-69 years, which was also observed in a survey of 60 elderly persons from two Rehabilitation Centers in São Luiz, Maranhão, of whom $53.3 \%$ were from the same age range as the present study ${ }^{9}$. In terms of gender, while it is known that leprosy affects men and women, some studies have indicated a prevalence among men, such as the World Health Organization's Global Leprosy Strategy 2016-2020: Accelerating Towards a World Without Leprosy, which found that only $36 \%$ of new cases in 2014 involved women ${ }^{10}$.

A study carried out in Colombia, a country where the prevalence of the disease has been less than $1 / 10000$ since 1997 , identified a ratio of one case in women for every 3.4 in men, with a mean age of 53 years, in which half of the patients were over 51 years old and the maximum age was 90 years ${ }^{11}$.

An epidemiological study that investigated cases in Brazil in 2001-2013 found that of 541,090 (99.5\%) individuals, $54.8 \%$ were men and $17.5 \%$ were aged 60 years or older ${ }^{12}$. In Ribeirão Preto, a municipal region in the state of São Paulo, a study found that of the 434 cases of leprosy in the period 2006-2013, there was a prevalence among men, with $60.83 \%$ of the tota ${ }^{13}$. In Araçatuba, São Paulo, an endemic municipal region in Brazil, a greater distribution was found among women, with 228 (52.5\%) of 434 cases examined in 2015. However, the difference was only 22 patients, with 206 (47.5\%) cases among men, which represents a reasonable difference. In terms of age group, $114(26.3 \%)$ patients were 60 years of age or older ${ }^{14}$.

This situation can be seen as a reflection of years of neglect of human health among men, who have become accustomed to not using health services and, consequently, have become more vulnerable to some diseases, especially serious and chronic illnesses. It was from this perspective that the Ministry of Health launched the National Policy for Integral Care for Men's Health in 2009, with the objective of encouraging health promotion actions aimed at this population ${ }^{15}$. Although leprosy can affect both genders, a reluctance to seek health care and being less concerned with the health-disease process, combined with an illness with chronic characteristics and transmission through intimate and prolonged contact, may combine to cause a prevalence of cases among this gender, contributing to an increased risk of illness ${ }^{16}$.

The sociodemographic data of the state of Alagoas is in keeping with the global reality regarding 
the process of population aging and the reduction of the fertility rate. Most of the population is made up of women, who have a life expectancy ten years greater than men. The gender ratio in the year 2015 was 91.7; while in the northeast of Brazil it was 93.8 and in the country as a whole it was 94.3. Of the municipal regions of the state, 58 out of 102 are classified as extremely poor, and the population of 12 municipal regions live in so-called 'subnormal communities', with a monthly income of between $1 / 4$ and $1 / 2$ minimum wage ${ }^{17,18}$.

In 2015 the illiteracy rate in the state was 20.0; while in the northeast it was 16.0 and in Brazil it was 8.0. This demonstrates the extent to which the state trails the national average in literacy and reflects the epidemiological indicators of the population. The unemployment rate is also above the average for the northeast and for Brazil, with a value of 15.3 for Alagoas; 10.3 for the northeast and 9.6 for the country as a whole ${ }^{18}$.

Health indicators based on the variables of ethnicity/skin color in cases of leprosy in Brazil reveal that the disease dominates among the black/ brown population, with 31,064 new cases detected in 2014. Of these, 21,554 cases occurred among the black population. Therefore, the Ministry of Health recommends a temporal study on this variable and the disease to understand distribution among this population group ${ }^{4}$.

In view of this, the present study does not contradict reality, as the occurrence of the disease was concentrated among illiterate individuals without a source of income and mixed-race individuals. As a public health problem, leprosy is strongly related to social context, reflecting the determinants and conditions of health to which the individual is submitted, which contributes significantly to an increased risk of illness, in addition to adding to the stigma and neglect of the disease, also linked to social conditions, making it difficult to tackle this public health problem ${ }^{19}$.

In general, leprosy can be classed as BP, which includes the indeterminate and tuberculoid clinical forms; and $\mathrm{MB}$, which are the dimorphic and Virchowian forms. The operational classification is based on the number of dermatological lesions, with $\mathrm{PB}$ cases containing up to five lesions and $\mathrm{MB}$ cases having more than five lesions ${ }^{20}$.

The present study found a predominance of the dimorphic clinical form and, consequently, of multibacillary cases, with more than five dermatological lesions. In terms of smear microscopy, the number of ignored and unrealized cases stands out. An epidemiological study carried out in Fortaleza, Ceará, between 2007 and 2011, obtained the same findings as the present study. The prevalent clinical form was dimorphic (48.0\%), followed by tuberculoid (31.4\%). MB cases accounted for more than half of the cases $(65.4 \%)$; while in Fortaleza smear microscopies were not performed in only $1.7 \%$ of cases $^{21}$. Data were similar to a study from the African continent conducted between 20052013, since the dimorphic clinical form and the MB operational classification prevailed, in addition to more than five tegumentary lesions ${ }^{22}$.

Deformities and physical disabilities are the main problems of the disease, generating physical and psychological harm, linked to a feeling of exclusion, stigma and prejudice that damages the health of the individual, as well as impairing the productive and financial development of the patient and affecting their family members ${ }^{23}$.

As for the grade of disability, there was a great concentration of 'not assessed' and 'ignored' answers in the diagnosis, along with an increase in this situation upon discharge. This reveals the negligence of health professionals with respect to their patients, since evaluation assists prevention and planning for the promotion and continuity of health care ${ }^{24}$.

The problem of incomplete data has been identified in other studies, which offer strategies to minimize the situation and strengthen epidemiological surveillance: the technical training of health teams working in health services where the incidence of the disease and underreported or incomplete data of cases is most exxpressive ${ }^{25}$, and the allocation of people with training in health surveillance to collaborate in the investigation and follow-up of cases $^{26}$. 
In a study conducted in Aracaju, capital of the state of Sergipe, with 2,358 patients, a predominance of grade zero (1,692 - 71.8\%) disability was observed. A cross-sectional study conducted in Fortaleza from November to December 2010 with a sample of 51 patients obtained some sociodemographic data similar to Alagoas. In terms of disability, 25 (49.1\%) patients with grade I or II disability were identified, while $14(27.5 \%) ; 11(21.6 \%)$ and $26(51.0 \%)$ of clients had grade zero disability ${ }^{27}$. According to the Ministry of Health, grade zero disability at the time of diagnosis is a national trend, revealing the importance of early diagnosis of notified cases as a leprosy control strategy ${ }^{4}$.

Neural impairment arises because the Hansen bacillus has a predilection for the peripheral nerves. It is therefore imperative that health professionals perform a neurofunctional evaluation, both at the time of diagnosis, halfway through treatment and at discharge, to investigate possible neurological disorders and allowing them to be treated quickly, aimed at the prevention of harm ${ }^{28}$.

A considerable portion of the patients in the present study were not assessed at the time of diagnosis. This fact is even more serious when it comes to the elderly, as more than half of those investigated were $\mathrm{MB}$, which can result in possible neural damage in patients who are already at risk of functional deficit.

The detection rate represents new cases per 100,000 inhabitants over a certain period ${ }^{29}$. In 2014, 213,899 patients were diagnosed globally, with $94 \%$ of this total concentrated in 13 countries, among which Brazil ranked second. In the elderly population in Alagoas, the detection rate of the study was above 20 per 100,000 inhabitants, with an average of 29.48, considered hyperendemic according to the parameters of the Ministry of Health.

\section{CONCLUSION}

It was found that an evaluation of physical disabilities caused by leprosy was carried out at diagnosis, there was a high proportion of cases with a grade 1 or II disability at the time of diagnosis, as well as a prevalence of multibacillary patients, indicating the need for improved early detection. There was a notable frequency of 'not evaluated' and 'ignored' physical disability, indicating that priority should be given to improving the notifications regarding such patients and investigating the difficulties faced by health professionals when registering such information.

Adequate and effective treatment against leprosy exists, but the required coverage of health services must be maintained, eliminating this pathology through a reduction in prevalence. Likewise, the disease can have negative implications in the lives of the elderly, with risks and harm for the social life of the individual.

It is important to understand the situation of the elderly population with leprosy in terms of their sociodemographic data. In this way, interventions to support recovery from leprosy, a disease with serious consequences if not treated early, can be made. National and international data on this theme are scarce. The present study provides information on the epidemiological profile of the elderly in Alagoas, contributing to the knowledge of the scientific community.

In conclusion, it is important to recognize the health situation of elderly persons who are carriers and ex-carriers of leprosy in the state of Alagoas, as knowing the epidemiology of the disease in this group allows the key components of health care to be identified, with the aim of minimizing the chances of the disease worsening.

\section{REFERENCES}

1. Organização Mundial da Saúde. Relatório Mundial de Envelhecimento e Saúde [Internet]. Genebra: OMS; 2015 [acesso em 28 dez. 2017]. Disponível em: http:// sbgg.org.br/wp-content/uploads/2015/10/OMSENVELHECIMENTO-2015-port.pdf
2. Nogueira PSF, Marques MB, Coutinho JFV, Maia JC, Silva MJ, Moura ERF. Fatores associados à capacidade funcional de idosos com Hanseníase. Ver Bras Enferm [Internet]. 2017 [acesso em 28 dez. 2017];70(4):711-

8. Disponível em: http://www.scielo.br/pdf/reben/ v70n4/pt_0034-7167-reben-70-04-0711.pdf 
3. Santos MIPO, Griep RH. Capacidade funcional de idosos atendidos em um programa do SUS em Belém. Ciênc Saúde Colet [Internet]. 2013 [acesso em 08 out. 2017];18(3):753-61. Disponível em: http:// www.scielo.br/scielo.php?script=sci_arttext\&pid $=$ S1413-81232013000300021

4. Brasil. Ministério da Saúde. Guia prático sobre a Hanseníase [Internet]. Brasília, DF: MS; 2017 [acesso em 20 dez. 2017]. Disponível em: http:// portalarquivos2.saude.gov.br/images/pdf/2017/ novembro/22/Guia-Pratico-de-Hanseniase-WEB.pdf

5. World Health Organization. Integrating neglected tropical diseases into global health and development: fourth WHO report on neglected tropical diseases [Internet]. Geneva: WHO; 2017. [acesso em 02 jan. 2018]. Disponível em: http://apps.who.int/iris/bitstre am/10665/255011/1/9789241565448-eng.pdf?ua=1

6. Brasil. Ministério da Saúde. Boletim epidemiológico: caracterização da situação epidemiológica da hanseníase e diferenças por sexo,Brasil, 2012-2016 [Internet]. 2018 [acesso em 27 fev. 2018]. Disponível em: http:// portalarquivos2.saude.gov.br/images/pdf/2018/ janeiro/31/2018-004-Hanseniase-publicacao.pdf

7. Viana LS, Aguiar MIF, Silva IR, Coutinho NPS, Aquino DMC. Social relationships and intimate dimensions of elderly individuais affected by hansen's disease. Cogitare Enferm [Internet]. 2015 [acesso em 08 jul. 2018];20(4):712-9. Disponível em: https:// revistas.ufpr.br/cogitare/article/view/41587/26646

8. Brasil. Ministério da Saúde. Diretrizes para vigilância, atenção e eliminação da Hanseníase como problema de saúde pública: manual técnico-operacional [Internet]. Brasília, DF: MS; 2016. [acesso em 2018 jan 02]. Disponível em: http://www.saude.pr.gov.br/arquivos/File/ DiretrizesdoManua'TcnicoOperacionaldeHansenase.pdf

9. Silva VL, Aguiar MIF, Vasconcelos PF, Aquino DMC. Aspecto físico e as repercussões na qualidade de vida e autonomia de idosos afetados por Hanseníase. Enferm Glob [Internet]. 2017 [acesso em 02 jan. 2018];46:350-

61. Disponível em: http://scielo.isciii.es/pdf/eg/ v16n46/pt_1695-6141-eg-16-46-00336.pdf

10. Organização Mundial da Saúde. Estratégia mundial de eliminação da lepra 2016-2020: acelerar a ação para um mundo sem lepra [Internet]. 2016 [acesso em 03 jan. 2018]. Disponível em: http://apps.who.int/iris/bit stream/10665/208824/17/9789290225201-pt.pdf

11. Romero-Montoya M, Beltran-Alzate JC, CardonaCastro. Evaluation and monitoring of Mycobacterium Leprae transmission in household contacts of patients with Hansen's Disease in Colombia. PLoS Negl Trop Dis [Internet]. 2017 [acesso em 02 jan. 2018];11(1):1-11. Disponível em: https://www.ncbi.nlm.nih.gov/pmc/ articles/PMC5289623/pdf/pntd.0005325.pdf
12. Nobre ML, Illarramendi X, Dupnik KM, Hacker MA, Nery JA, Jerônimo SM, et al. Multibacillary leprosy by population groups in Brazil: lessons from an observational study. PLoS Negl Trop Dis [Internet] 2017 [acesso em 02 jan. 2018];11(2):1-14. Disponível em: https://www.ncbi.nlm.nih.gov/pmc/ articles/PMC5325588/pdf/pntd.0005364.pdf

13. Ramos ACV, Yamamura M, Arroyo LH, Popolin MP, Chiaravalloti Neto F, Palha PF, et al. Spatial clustering and local risk of leprosy in São Paulo, Brazil. PLoS Negl Trop Dis [Internet]. 2017 [acesso em 02 jan. 2018];11(2):1-15. Disponível em: https:// www.ncbi.nlm.nih.gov/pmc/articles/PMC5344525/ pdf/pntd.0005381.pdf

14. Martins RJ, Carloni MEOG, Moimaz SAS, Garbin CAS, Garbin AJI. Sociodemographic and epidemiological profile of leprosy patients in an endemic region in Brazil. Rev Soc Bras Med Trop [Internet]. 2016 [acesso em 02 jan. 2018];49(6):77780. Disponível em: http://www.scielo.br/pdf/rsbmt/ v49n6/0037-8682-rsbmt-49-06-00777.pdf

15. Chakora ES. Política Nacional de Atenção Integral à Saúde do Homem. Esc Anna Nery [Internet]. 2014 [acesso em 02 jan. 2018];18(4):559-61. Disponível em: http://www.scielo.br/pdf/ean/v18n4/1414-8145ean-18-04-0559.pdf

16. Barbosa DRM, Almeida MG, Santos AG. Características epidemiológicas e espaciais da Hanseníase no Estado espaciais da Hanseníase no Estado do Maranhão, Brasil, 2001-2012. Medicina (Ribeirão Preto) [Internet]. 2014 [acesso em 02 jan. 2018];47(4):347-56. Disponível em: http://revista.fmrp.usp.br/2014/vol47n4/ REV_Caracteristicas-epidemiologicas-e-espaciais-dahanseniase-no-Estado-do-Maranhao.pdf

17. Alagoas. Secretaria do Estado da Saúde. Plano Estadual de Saúde 2016-2019 [Internet]. Maceió: SES; 2016. [acesso em 02 jan. 2018]. Disponível em: http://cidadao.saude.al.gov.br/wp-content/ uploads/2016/07/Plano-Estadual-de-Sa\%C2\%A6dePES-2016-2019.pdf

18. Alagoas. Secretaria de Estado do Planejamento, Gestão e Patrimônio. Indicadores Básicos de Alagoas [Internet]. Vol. 3. Maceió: SEPLAG; 2017 [acesso em 02 jan. 2018]. Disponível em: http://dados.al.gov. br/dataset/79fa1657-a13f-41a2-9087-95d1fc8ca12b/ resource/d2c97b5a-fe1b-4f74-b63b-1a267c37e47f/ download/indicadoresbasicos.pdf

19. Lopes VA, Rangel EM. Hanseníase e vulnerabilidade social: uma análise do perfil socioeconômico de usuários em tratamento irregular. Saúde Debate [Internet]. 2014 [acesso em 02 jan. 2018];38(103):81729. Disponível em: http://www.scielo.br/pdf/sdeb/ v38n103/0103-1104-sdeb-38-103-0817.pdf 
20. Barreto JA. Diagnóstico laboratorial da Hanseníase: indicações e limitações. In: Alves ED, Ferreira TL, Ferreira IN. Hanseníase: avanços e desafios. Brasília, DF: NESPROM; 2014. p. 131-40.

21. Queirós MI, Alencar CHM, Sena AL, Ramos-Júnior ANR, Monteiro LD, Barbosa JC. Clinical and epidemiological profile of leprosy patients attended at Ceará, 2007-2011. An Bras Dermatol [Internet]. 2016 [acesso em 02 jan. 2018];91(3):311-7. Disponível em: http://www.scielo.br/pdf/abd/v91n3/0365-0596abd-91-03-0311.pdf

22. Camuset G, Lafarge S, Borgherini G, Gerber A, Pouderoux N, Foucher A, et al. Leprosy on Reunion Island, 2005-2013: Situation and Perspectives. PLoS Negl Trop Dis [Internet]. 2016 [acesso em 02 jan. 2018];10(4):1-8. Disponível em: https://www. ncbi.nlm.nih.gov/pmc/articles/PMC4833340/pdf/ pntd.0004612.pdf

23. Silveira MGB, Coelho AR, Rodrigues SM, Soares MM, Camillo GN. Portador de hanseníse: impacto psicológico do diagnóstico. Psicol Soc [Internet]. 2014 [acesso em 02 jan. 2018];26(2):517-27. Disponível em: http://www.scielo.br/pdf/psoc/ v26n2/a27v26n2.pdf

24. Uchôa REMN, Brito KKG, Santana EMF, Soares VL, Silva MA. Clinical profile and physical disabilites in patients with leprosy. J Nurs UFPE on line [internet]. 2017 [acesso em 08 jul. 2018];11(suppl.3):1464-72. Disponível em: https:// periodicos.ufpe.br/revistas/revistaenfermagem/ article/view/13990/16851
25. Pinheiro RS, Andrade VL, Oliveira GP. Subnotificação da tuberculose no Sistema de Informação de Agravos de Notificação (SINAN): abandono primário de bacilíferos e captação de casos em outras fontes de informação usando linkage probabilístico. Cad Saúde Pública [Internet]. 2012 [acesso em 02 jan. 2018];28(8):1559-68. Disponível em: http://dx.doi. org/10.1590/S0102-311X2012000800014

26. Lírio M, Santos NP, Passos LA, Kritski A, GalvãoCastro B, Grassi MF. Completude das fichas de notificação de Tuberculose nos municípios prioritários da Bahia para controle da doença em indivíduos com HIV/AIDS. Ciênc Saúde Colet [Internet]. 2015 [acesso em 08 jul. 2018];20(4):1143-8. http://dx.doi. org/10.1590/1413-81232015204.00672014

27. Santos VS, de Matos AM, de Oliveira LS, de Lemos LM, Gurgel RQ, Reis FP, et al. Clinical variables associated with disability in leprosy cases in northeast Brazil. J Infect Dev Ctries [Internet]. 2015 [acesso em 03 jan. 2018];9(3):232-8. Disponível em: https://jidc. org/index.php/journal/article/view/25771459/1260

28. Mesquita R, Melo LTM, Vasconcelos RS, Soares DM, Félix GAA, Férrer LPA, et al. Avaliação neurofuncional em pacientes com Hanseníase. Rev Bras Promoç Saúde [Internet]. 2014 [acesso em 03 jan. 2018];27(2):247-55. Disponível em: http://www. redalyc.org/pdf/408/40833375014.pdf

29. Brasil. Ministério da Saúde. Boletim epidemiológico: situação epidemiológica da Hanseníase no Brasil: análise de indicadores selecionados na última década e desafios para eliminação [Internet]. 2013 [acesso em 03 jan 2018];44(11):1-12. Disponível em: http:// portalarquivos2.saude.gov.br/images/pdf/2014/ junho/11/BE-2013-44--11----Hanseniase.pdf 